\section{References}

Abrams, R. L., Cerchio, G. M., and Graber, A. L. (1968). Diabetes, 17, 314. Baker, I. A., and Jarrett, R. J. (1972). Lancet, 2, 945.

Baker, P. G. B., and Mottram, R. F. (1973). Clinical Science, 44, 479.

Bowen, A. J., and Reeves, R. L. (1967). Archives of Internal Medicine, 119, 261 .

Butterfield, W. J. H., Abrams, M. E., St. John, D. J. B., and Whichelow, M. J. (1967). Metabolism, 16, 19.

Carroll, K. F., and Nestel, P. J. (1973). Diabetes, 22, 333.

Carruthers, M., and Young, D. A. B. (1973). In Automation in Analytical Chemistry, ed. L. T. Skeegs. In press.

Duncan, L. J. P. (1956). Quarterly Fournal of Experimental Medicine, 41, 85. Gibson, T., and Jarrett, R. J. (1972). Lancet, 2, 947.
Jarrett, R. J., and Keen, H. (1969). British Medical fournal, 2, 341.

Jarrett, R. J., and Keen, H. (1970). British Medical foutnal, 4, 334

Jarrett, R. J., Baker, I. A., Keen, H., and Oakley, N. W. (1972). British Medical fournal, $1,199$.

undbaek, K. (1962). British Medical Fournal, 1, 1507.

Nemeth, S., Vigas, M., Macho, L., and Stukovsky, R. (1970). Diabetologia, 6, 641 .

Oakley, N. W., Monier, D., and Wynn, V. (1973). Diabetologia, 9, 235.

Randle, P. J., Garland, P. B., Hales, C. N., and Newsholme, E. A. (1963). Lancet, $1,785$.

Roberts, H. J. (1964). Fournal of the American Geriatrics Society, 12, 423.

Whichelow, M. J., and Butterfield, W. J. H. (1971). Quarterly fournal of Medicine, 40, 261 .

Zimmet, P. Z., Wall, J. R., Rome, R., Stimmler, L., and Jarrett, R. J. (1974). British Medical fournal. In press.

\title{
Aspirin and Anaemia in Childhood
}

\author{
H. HEGGARTY
}

British Medical fournal, 1974, 1, 491-492

\section{Summary}

Chronic aspirin ingestion in childhood is not uncommon, often goes undetected, and may cause serious anaemia from occult blood loss. Five cases are described.

\section{Introduction}

Acute aspirin poisoning is an emergency in paediatric practice but the dangers of chronic aspirin ingestion by children are not sufficiently recognized. Marshall and Kuzemko (1972) drew attention to aspirin-induced haematemesis in three children. This paper describes five children in whom significant anaemia seemed clearly related to chronic aspirin ingestion.

\section{Case Reports}

Case 1.-A 3-year-old boy was admitted to hospital because of pallor of three weeks' duration. His dietary intake had been normal, there was no history of blood loss, and drug ingestion was denied by the parents. Only pallor was found on examination. Haemoglobin was $5.2 \mathrm{~g} / 100 \mathrm{ml}$ and the blood showed an iron deficiency pattern. The results of extensive investigations, including coagulation studies, faecal fat analysis, and barium studies, were normal. Faecal occult blood tests gave positive results for the first four days. The anaemia responded promptly to iron therapy. On followup at outpatient clinics repeated history taking showed that for over six months before admission the boy had been taking one "junior" $150-\mathrm{mg}$ aspirin tablet nightly as a sedative, prescribed by his family doctor, plus two such tablets daily if "unwell in any way." Thereafter he stopped taking aspirin, he remained well, and anaemia did not recur over a two-year follow-up period.

Case 2.-A 3-year-old boy was admitted to hospital with a sixweek history of progressive pallor. His diet was normal and his parents denied any history of bleeding or drug ingestion. Pallor was the only abnormal clinical finding. Haemoglobin was 4.3 $\mathrm{g} / 100 \mathrm{ml}$ and the blood film showed an iron-deficiency pattern. The results of stool occult blood tests were positive on the first three days after admission but negative thereafter. Barium studies showed nothing abnormal in the gastrointestinal tract. Malabsorption and coagulation defects were excluded. The anaemia responded

Friarage Hospital, Northallerton DL6 1JG

H. HEGGARTY, M.B., M.R.C.P., Consultant Paediatrician to iron therapy and did not recur over a three-year follow-up period. From repeated history taking it emerged that the boy had been taking two or three $300-\mathrm{mg}$ aspirin tablets daily for many months administered as a "sedative" by a relative.

Case 3.-A 14-year-old boy was admitted to hospital with a sixmonth history of listlessness, pallor, and dyspnoea on effort. He had fainted three times during the previous two weeks. He denied drug ingestion. Pallor and koilonychia were the only abnormal physical signs. Haemoglobin was $5.8 \mathrm{~g} / 100 \mathrm{ml}$ and the blood film was classcial of iron deficiency. The results of faecal occult blood tests were positive for the first five days. Haemolysis and coagulation deficits were excluded. The anaemia responded promptly and permanently to iron therapy. After repeated questioning the boy disclosed that he had been taking $600 \mathrm{mg}$ of aspirin daily and often $600 \mathrm{mg}$ at night also for over six months "to relieve mild toothaches, headaches, and sleeplessness."

Case 4.-The patient was a 12-year-old girl who complained of recurrent abdominal pain and headaches for four months. Her diet was normal and drug ingestion was denied. The only abnormal physical finding was pallor. Haemoglobin was $7.1 \mathrm{~g} / 100 \mathrm{ml}$ and a blood film showed iron deficiency. Initial results of stool occult blood tests were positive. Studies of coagulation and absorption showed these to be normal. The gastrointestinal tract appeared normal on barium radiography. The anaemia responded to iron therapy and did not recur over a two-year follow-up period. Her original symptoms also disappeared. At her third follow-up attendance she admitted having taken $600-1,200 \mathrm{mg}$ of aspirin daily for four months before her admission to hospital.

Case 5.-The patient was an 8-month-old infant who was noted to be pale at a routine clinical examination. The parents had not been concerned. Birth, dietary, and developmental histories were normal. The parents denied any drug ingestion. Apart from pallor there were no clinical findings. Haemoglobin was $7.4 \mathrm{~g} / 100 \mathrm{ml}$ and the blood film showed iron deficiency. Stool occult blood tests gave positive results, but the results of detailed haematological tests were normal. On closer questioning the parents admitted that the baby had received two "junior" $150-\mathrm{mg}$ aspirin tablets daily for the previous six to eight weeks for febrile episodes, teething, and as a sedative. Aspirin was stopped, the anaemia responded to iron therapy, and the baby remained well over a six-month follow-up period.

\section{Discussion}

The diagnosis of chronic bleeding from the gastrointestinal tract induced by aspirin ingestion can be made only empirically. The similar clinical patterns in the five children, the absence of other explanations despite thorough investigation, and the complete recoveries when aspirin was stopped suggest that the drug ingestion caused the anaemia. The bleeding may be alarmingly obvious (Marshall and Kuzemko, 1972) but was occult in the group of children described above. The value of a careful history needs to be re-emphasized. Patients 
and parents do not consider aspirin as a drug and they should be questioned specifically about salicylate ingestion. Often it is admitted only after three or four sessions of history taking or when relatives other than parents are questioned.

Salicylates are valuable in the treatment of acute rheumatism and rheumatoid arthritis but are grossly overprescribed for relatively trivial and self-limiting conditions in childhood. The medical profession must shoulder responsibility for this, particularly those doctors who prescribe aspirin for children without examining them. Moreover, aspirin is easily obtainable without prescription and its value is constantly extolled in adventisements. The dangers of chronic aspirin ingestion by adults are well recognized and every paediatrician is aware of the perils of acute aspirin poisoning. It is also well known that $70 \%$ of adults who take aspirin over a long period lose about $2 \mathrm{ml}$ of blood per day but there have been no studies of the effects of chronic aspirin ingestion on normal children. These cases reponted here emphasize that chronic aspirin ingestion in childhood is not uncommon, often goes undetected, and may cause serious anaemia.

I should like to thank Dr. R. R. Gordon, consultant paediatrician, for permission to study patients under his care, and Miss Margaret Swall for secretarial help.

\section{Reference}

Marshall, N., and Kuzemko, J. A. (1972). British Medical fournal, 4, 612.

\section{MEDICAL MEMORANDA}

\section{Progressive External Ophthalmo- plegia and Heart Block}

\section{J. B. PILling, M. A. NANTON}

British Medical fournal, 1974, 1, 492-493

Disturbances of cardiac conduction are a well-recognized feature of some neurodegenerative disorders. We report an example of an uncommon syndrome in which complete heart block with Adams-Stokes attacks may occur at a time when the disability from the neurological condition is slight.

\section{Case Report}

A 23-year-old female laundry worker was admitted to hospital after losing consciousness suddenly at work. There were no convulsive movements. On admission her conscious level fluctuated between coma and drowsiness with response to command. Two months previously she had developed pain and difficulty in lifting her arms after unaccustomed exertion. These symptoms disappeared after one week but she felt slightly unwell, though able to continue at work, until the syncopal attack. Birth and development had been normal and the menarche had ocourred when she was 14 years old. None of her family were aware of a change in her appearance but photographs showed the development of bilateral ptosis by the age of 20 years.

Information was available on 72 members in four generations of the family and there were no instances of sudden death or of progressive neurological disorders; 14 members were examined and all were of short stature-for example, the father was 63 in $(160 \mathrm{~cm})$ tall. Her father had evidence of healed specific choroiditis and a cousin had Down's syndrome.

Examination showed a woman of small stature (height 55 in $(140 \mathrm{~cm})$; weight $72 \mathrm{lb}(32.6 \mathrm{~kg})$ ) and low average intelligence. There was bilateral ptosis and almost complete paralysis of voluntary and reflex eye movement in all directions. The pupils were equal, with normal light reflexes. Visual acuity was $6 / 6$ bilaterally (Snellen). Visual fields were normal. The ocular fundi showed

\section{United Cambridge Hospitals}

J. B. PILLING, M.B., M.R.C.P., Registrar, Department of Neurology M. A. NANTON, M.B., M.R.C.P., Senior Registrar, Department of Cardio$\log y$ fine stippling due to pigmentary degeneration. There was no facial weakness and though the limbs were thin there was no evidence of focal wasting or weakness. There was no ataxia. All tendon reflexes were present and the plantar responses were flexor. There was no sensory impairment.

An irregular bradycardia of $45-60 / \mathrm{min}$ was present. Brachial artery pressure was $100 / 70 \mathrm{~mm} \mathrm{Hg}$. The heart was not enlarged, heart sounds were normal, and there was no evidence of congestive cardiac failure.

On investigation the blood count, result of urine analysis, urea and electrolytes, serum proteins and electrophoretic pattern, and serum creatine phosphokinase were all normal. The serum enzymes were: SGOT $36 \mathrm{U} / \mathrm{ml}$, SGPT $26 \mathrm{U} / \mathrm{ml}$. Serology was negative for syphilis. The chest $x$-ray picture was normal. Chromosome analysis showed a normal female karyotype. E.E.G. showed a slight paroxysmal tendency but no persistent focal or specifically epileptic abnormalities. Audiology showed a mild sensorineural deafness.

E.C.G. showed complete heart block with multifocal ventricular pacemakers. There were runs of ventricular tachycardia and episodes of ventricular fibrillation (see fig.).

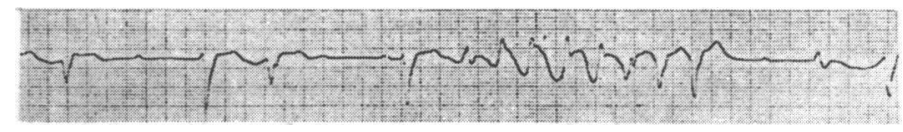

E.C.G. showing runs of ventricular tachycardia and episodes of ventricular fibrillation.

She was resuscitated successfully from several episodes of ventricular fibrillation, after which a temporary transvenous pacing catheter was inserted. She was treated with prednisolone $30 \mathrm{mg}$ daily for five weeks but there was no sign of recovery of atrioventricular conduction and a permanent pacemaking system (Lucas) was implanted. Apart from a short period during which exit block occurred she remained well and continued to be paced satisfactorily. Twenty months later there was no progression of her neurological disability.

\section{Comment}

Cases of progressive external ophthalmoplegia with complete heart block have been described by Sandifer (1946), Jager et al. (1960), Kearns (1965) (three cases), Daroff et al. (1966), Drachman (1968) (two cases), Ross et al. (1969), and Shastri et al. (1971) - a total of 10 cases, in eight of which patients experienced Adams-Stokes attacks, three eventually dying during an attack. Three were treated successfully with cardiac pacemakers. 